\title{
Analisis Faktor Yang Mempengaruhi Volume ASI Perah Ibu Menyusui Selama Bekerja Di Lingkungan Universitas NU Surabaya
}

\author{
Esty Puji Rahayu \\ Universitas NU Surabaya, esty@unusa.ac.id \\ Nur Masruroh \\ Universitas NU Surabaya, nurmasruroh@unusa.ac.id
}

\begin{abstract}
Abstrak
Makanan yang paling ideal untuk bayi adalah Air Susu Ibu (ASI), namun demikian karena beberapa hal bayi tidak dapat memperoleh ASI karena beberapa alasan seperti kesehatan ibu dan bekerja di luar rumah. Faktor yang menghambat keberhasilan menyusui pada ibu bekerja adalah pendeknya waktu cuti kerja, kurangnya dukungan tempat kerja, pendeknya waktu istirahat saat bekerja (tidak cukup waktu untuk memerah ASI), tidak adanya ruangan untuk memerah ASI, pertentangan keinginan ibu antara mempertahankan prestasi kerja dan produksi ASI. Salah satu masalah yang sering dihadapi ibu-ibu yang hendak menabung ASIP adalah hasil perah/pumping yang kurang memuaskan. Penelitian ini menjelaskan faktor yang mempengaruhi volume ASI Perah dengan desain penelitian deskriptif kualitatif, melalui pendekatan cross sectional dengan sampel ibu bekerja yang memompa ASI di lingkungan UNUSA. Hasil penelitian menunjukkan bahwa faktor yang paling berhubungan dengan volume ASI perah adalah paritas ( $\mathrm{p}$ value 0,012 ), keyakinan ibu untuk bisa memberikan ASI ( $\mathrm{p}$ value 0,009 ) dan frekuensi memerah ( $\mathrm{p}$ value 0,041 ). Usia ibu, indeks massa tubuh ibu, alat yang digunakan untuk memompa, tempat memompa dan alat kontrasesepsi tidak berhubungan secara signifikan dengan volume ASI Perah. Perceptions of Insufficient Milk Supply in Breastfeeding (PIM) adalah pendapat dimana ibu meyakini bahwa dia memiliki supplai ASI yang kurang/tidak cukup untuk memenuhi kebutuhan bayinya. Jika ibu kurang yakin akan suplay ASInya maka akan menurun juga hasil memompanya. Apabila seorang ibu mempunyai pengalaman memompa ASI pada anak sebelumnya tentu akan mempengaruhi keyakinan dan persepsi ibu dalam memberikan ASI sehingga paritas juga akan mempengaruhi volume ASIP.
\end{abstract}

Kata Kunci: Volume ASI Perah, Ibu Menyusui, Ibu Bekerja.

\begin{abstract}
The most ideal food for babies is breast milk, but for some reasons babies cannot get breast milk such as maternal health and working outside the home. Factors that hinder the success of breastfeeding in working mothers are short time off work, lack of workplace support, short breaks at work (not enough time to pumping), lack of room to pumping, conflict between mother's desire to maintain work performance and breastmilk production. One problem that is often faced by mothers who want to save dairy breastmilk is the unsatisfactory result of pumping. In this study explained the factors that influence the volume of dairy breastmilk using a qualitative descriptive research design with a cross-sectional approach with samples of working mothers who pump breast milk at UNUSA. The results showed that the factor most associated with the volume of dairy breastmilk was parity ( $\mathrm{p}$ value 0.012), Perceptions of Insufficient Milk Supply in Breastfeeding ( $\mathrm{p}$ value 0.009) and the frequency of milking ( $\mathrm{p}$ value 0.041). Mother's age, body mass index, devices used for pumping, pumping sites and contraceptive are not significantly associated with the volume of breast milk. Perceptions of Insufficient Milk Supply in Breastfeeding (PIM) is mother's opinion who believe that they have a supply of breast milk that is not enough for babies. If the mother is not sure that she will supply ASI, the pumping will also decrease. If a mother has the experience of pumping breast
\end{abstract}


milk in a child beforehand it will certainly affect the mother's beliefs and perceptions in giving breast milk so that parity will also affect dairy breastmilk volume.

Keywords: factors, dairy breast milk, working mothers

\section{PENDAHULUAN}

Air Susu Ibu (ASI) adalah suatu emulsi lemak dalam larutan protein, laktosa dan garam-garam organik yang disekresikan oleh kedua belah kelenjar payudara ibu yang berguna untuk makanan utama bagi bayi (Roesli, 2012). Menurut Perinasia (2004) ASI merupakan makanan yang mudah didapat, selalu tersedia, siap diminum tanpa ada persiapan khusus dan memiliki termperatur yang sesuai dengan bayi.Pemberian ASI memiliki banyak manfaat bagi ibu dan bayi. Beberapa manfaat

ASI bagi bayi yaitu sebagai perlindungan terhadap infeksi gastrointestinal, menurunkan risiko kematian bayi akibat diare dan infeksi, sumber energi dan nutrisi bagi anak usia 6 sampai 23 bulan, serta mengurangi angka kematian di kalangan anak-anak yang kekurangan gizi. Sedangkan manfaat pemberian ASI bagi ibu yaitu mengurangi risiko kanker ovarium dan payudara, membantu kelancaran produksi ASI, sebagai metode alami pencegahan kehamilan dalam enam bulan pertama setelah kelahiran, dan membantu mengurangi berat badan lebih dengan cepat setelah kehamilan (WHO, 2016).
Survey Demografi Kesehatan Indonesia (SDKI) 2007 menunjukkan bahwa 57\% tenaga kerja di Indonesia adalah wanita. Faktor yang menghambat keberhasilan menyusui pada ibu bekerja adalah pendeknya waktu cuti kerja, kurangnya dukungan tempat kerja, pendeknya waktu istirahat saat bekerja (tidak cukup waktu untuk memerah ASI), tidak adanya ruangan untuk memerah ASI, pertentangan keinginan ibu antara mempertahankan prestasi kerja dan produksi ASI.

Salah satu masalah yang sering dihadapi ibu-ibu yang hendak menabung ASIP adalah hasil perah/pumping yang kurang memuaskan. Banyak ibu-ibu yang merasa tidak puas dengan hasil pumping dan merasa pompa (jika menggunakan bantuan pompa) yang dibeli tidak memberikan hasil maksimal dan bergegas ingin berganti pompa baru.

Kunci utama dalam pumping adalah bagaimana memicu Let down reflex (LDR) atau pelepasan ASI. Beberapa ibu merasakan ada sensasi geli (tingling), sebagian lain tidak merasakan apa-apa. Pelepasan ini dapat dipicu seperti oleh sentuhan pada payudara, tangisan bayi, bahkan pikiran tentang bayi. Perasaan sedih, marah, tegang menghambat 
pelepasan ini. Tanpa munculnya let down atau pelepasan ASI ini, Ibu hanya bisa menghasilkan sedikit ASI yang terkumpul hanya di ujung putting, sehingga kunci utama dalam pumping adalah bagaimana memicu LDR ini.

Produksi ASI sangat dipengaruhi oleh makanan yang dimakan ibu, apabila makanan ibu secara teratur dan cukup mengandung gizi yang diperlukan akan mempengaruhi produksi ASI, karena kelenjar pembuat ASI tidak dapat bekerja dengan sempurna tanpa makanan yang cukup. Untuk membentuk produksi ASI yang baik, makanan ibu harus memenuhi jumlah kalori, protein, lemak, dan vitamin serta mineral yang cukup selain itu ibu dianjurkan minum lebih banyak kurang lebih 8-12 gelas/hari.

Faktor psikologis ibu yang mempengaruhi kurangnya produksi ASI antara lain adalah ibu yang berada dalam keadaan stress, kacau, marah dan sedih, kurang percaya diri, terlalu lelah, ibu tidak suka menyusui, serta kurangnya dukungan dan perhatian keluarga dan pasangan kepada ibu. Selain itu puting lecet, pembengkakan dan nyeri akibat insisi juga menjadi faktor yang mempengaruhi produksi ASI. Faktor ketidaknyamanan yang ibu rasakan sering menyebabkan ibu berhenti untuk menyusui. Dengan berhenti menyusui maka rangsang isapan bayi akan berkurang sehingga produksi ASI akan menurun

\section{METODE}

Desain penelitian yang digunakan adalah deskriptif kuantitatif pendekatan cross sectional dimana pengukuran variable dilakukan satu kali. Populasinya adalah ibu bekerja yang menyusui di lingkungan UNUSA. Tehnik pengambilan sampel menggunakan teknik purposive sampling dimana pengambilan sampel yang memenuhi kriteria peneliti. Jumlah sampel sebanyak 10 orang. Peneliti mengajukan permohonan pelaksanaan penelitian dari LPPM Universitas Nahdlatul Ulama Surabaya kepada responden, setelah mendapatkan ijin peneliti kemudian melakukan pendekatan kepada responden dan menjelaskan tentang prosedur pelaksanaan penelitian serta melakukan informed consent selanjutnya dilakukan wawancara, pengisian kuesioner dan observasi. Instrumen penelitian yang digunakan adalah lembar kuesioner yang diberikan kepada responden tentang faktor yang mempengaruhi volume ASI perah. Pengumpulan data dilakukan dengan cara merekap hasil observasi kemudian menganalisis data dengan menggunakan uji Spearman dan Pearson Test. 


\section{HASIL PENELITIAN}

1. Karakteristik responden berdasarkan usia Karakteristik responden berdasarkan usia akan disajikan dalam tabel distribusi frekuensi sebagai berikut:

Tabel 4.1 Distribusi frekuensi responden menurut umur

\begin{tabular}{cccc}
\hline No & Umur (th) & Frekuensi & Persentase (\%) \\
\hline 1. & $25-30$ & 4 & 40 \\
2. & $31-35$ & 4 & 40 \\
3. & $36-40$ & 2 & 20 \\
\hline & Jumlah & 10 & 100 \\
\hline
\end{tabular}

Tabel 4.1 menunjukkan bahwa dari 10 responden $80 \%$ berada pada usia produktif yaitu usia 25-35 tahun.

2. Karakteristik responden berdasarkan paritas. Karakteristik responden berdasarkan paritas akan disajikan dalam tabel distribusi frekuensi sebagai berikut:

Tabel 4.2 Distribusi frekuensi responden menurut paritas

\begin{tabular}{clcc}
\hline No & Paritas & Frekuensi & Persentase (\%) \\
\hline 1. & Primipara & 2 & 20 \\
2. & Multipara & 8 & 80 \\
\hline & Jumlah & 10 & 100 \\
\hline
\end{tabular}

Tabel 4.2 menunjukkan bahwa dari 10 responden hampir seluruhnya (80\%) multipara.

3. Karakteristik responden berdasarkan indeks massa tubuh

Tabel 4.3 Distribusi frekuensi responden menurut Indeks Masa Tubuh

\begin{tabular}{cccc}
\hline No & IMT Ibu & Frekuensi & Persentase (\%) \\
\hline 1. & Kurus & 0 & 0 \\
2. & Normal & 2 & 20 \\
3. & Kegemukan & 5 & 50 \\
4. & Obesitas & 3 & 30 \\
\hline & Jumlah & 10 & 100 \\
\hline
\end{tabular}

Tabel 4.3 menunjukkan bahwa responden 50\% mengalami kegemukan.

4. Karakteristik responden berdasarkan Perceptions of Insufficient Milk Supply in Breastfeeding (PIM)

Tabel 4.4 Distribusi frekuensi responden berdasarkan Perceptions of Insufficient Milk Supply in Breastfeeding

\begin{tabular}{clcc}
\hline No & Persepsi Ibu & Frekuensi & $\begin{array}{l}\text { Persentase } \\
(\%)\end{array}$ \\
\hline 1. & Yakin & 7 & 70 \\
2. & Tidak yakin & 3 & 30 \\
\hline & Jumlah & 10 & 100 \\
\hline
\end{tabular}

Tabel 4.4 menunjukkan bahwa $70 \%$ ibu yakin akan suplai ASI untuk buah hatinya bisa sampai 2 tahun.

5. Karakteristik responden berdasarkan alat yang digunakan untuk memompa

Tabel 4.5 Distribusi frekuensi responden berdasarkan alat yang digunakan untuk memompa

\begin{tabular}{cccc}
\hline No & Alat yang digunakan & $\begin{array}{l}\text { Frekue } \\
\text { nsi }\end{array}$ & $\begin{array}{l}\text { Persentas } \\
\mathrm{e}(\%)\end{array}$ \\
\hline 1. & Manual breastpump & 3 & 30 \\
2. & Electric singlepump & 6 & 60 \\
3. & Electric dualpump & 1 & 10 \\
\hline & Jumlah & 10 & 100 \\
\hline
\end{tabular}

Tabel 4.5 didapatkan data bahwa paling bnayak responden menggunakan alat electric single pump saat memompa ASI di tempat bekerja

6. Karakteristik responden berdasarkan frekuensi memerah selama bekerja 
Tabel 4.6 Distribusi frekuensi responden berdasarkan frekuensi memerah selama bekerja.

\begin{tabular}{clcc}
\hline No & $\begin{array}{l}\text { Frekuensi } \\
\text { memerah }\end{array}$ & Frekuensi & Persentase (\%) \\
\hline 1. & 1 kali & 3 & 30 \\
2. & 2 kali & 5 & 50 \\
3. & 3 kali & 2 & 20 \\
\hline & Jumlah & 10 & 100 \\
\hline
\end{tabular}

Berdasarkan tabel 4.6 dapat dilihat bahwa sebagian responden memompa sebanyak 2 kali selama bekerja

7. Karakteristik responden berdasarkan tempat memompa

Tabel 4.7 Distribusi frekuensi responden berdasarkan tempat memompa

\begin{tabular}{llrc}
\hline No & $\begin{array}{l}\text { Tempat memompa } \\
\text { ASI }\end{array}$ & $\begin{array}{l}\text { Freku } \\
\text { ensi }\end{array}$ & $\begin{array}{l}\text { Persentas } \\
\text { e (\%) }\end{array}$ \\
\hline 1. & $\begin{array}{l}\text { Tempat duduk (meja } \\
\text { karyawan) }\end{array}$ & 6 & 60 \\
2. & $\begin{array}{l}\text { Ruang laktasi } \\
\text { Musholla / tempat } \\
\text { lain }\end{array}$ & 3 & 10 \\
& & 30 \\
\hline Jumlah & 10 & 100 \\
\hline
\end{tabular}

Tabel 4.8 didapatkan data bahwa hanya

$10 \%$ yang memanfaatkan ruang laktasi yang ada di Kampus A UNUSA.

8. Karakteristik responden berdasarkan penggunaan alat kontrasepsi

Tabel 4.8 Distribusi frekuensi responden berdasarkan alat kontrasepsi yang digunakan

\begin{tabular}{llcc}
\hline No & Alat kontrasepsi & $\begin{array}{l}\text { Frekue } \\
\text { nsi }\end{array}$ & $\begin{array}{l}\text { Persentase } \\
(\%)\end{array}$ \\
\hline 1. & Tidak & 4 & 40 \\
& menggunakan & 3 & 30 \\
2. & Hormonal & 3 & 30 \\
3. & Nonhormonal & 10 & 100 \\
\hline \multicolumn{2}{l}{ Jumlah } & 10 \\
\hline
\end{tabular}

Tabel 4.8 di atas didapatkan data bahwa masih terdapat $40 \%$ responden yang tidak menggunakan alat kontrasepsi.
9. Hubungan IMT dengan volume ASI Perah

Analisis data menggunakan Pearson Test didapatkan hasil bahwa tidak ada hubungan antara IMT ibu dengan volume ASI perah dengan $p$ value 0,338

10. Hubungan Paritas dengan volume ASI Perah'

Analisis data menggunakan Pearson Test didapatkan data bahwa terdapat hubungan yang signifikan antara paritas dengan volume ASI perah dengan $p$ value 0,012

11. Hubungan Usia Ibu dengan volume ASI Perah

Analisis data menggunakan Pearson Corelation didapatkan hasil bahwa tidak ada hubungan antara usia ibu dengan volume ASI Perah dengan $p$ value 0,112

12. Hubungan Perceptions of Insufficient Milk Supply in Breastfeeding (PIM) dengan volume ASI Perah

Analisis data menggunakan Spearman Rank Test didapatkan hasil bahwa persepsi ibu berhubungan secara signifikan dengan volume ASI Perah dengan $p$ value 0,009

13. Hubungan alat yang digunakan untuk memompa dengan volume ASI Perah Analisis data menggunakan Spearman Rank Test menunjukkan hasil tidak ada hubungan antara alat yang digunakan untuk memompa dengan volume ASI Perah dengan $p$ value 0,985 
14. Hubungan frekuensi memerah dengan volume ASI perah

Analisis data menggunakan Pearson Test disimpulkan bahawa terdapat hubungan yang signifikan antara volume ASI Perah dengan frekuensi memerah selama bekerja dengan $p$ value 0,041 .

15. Hubungan tempat memompa dengan volume ASI perah

Analisis data menggunakan Spearman Test dapat disimpulkan bahwa tempat memompa tidak berhubungan dengan volume ASI Perah dengan $p$ value 0,519

16. Hubungan alat kontrasepsi dengan volume ASI Perah

Analisis data menggunakan Spearman Test disimpulkan bahwa tidak terdapat hubungan antara alat kontrasepsi dengan volume ASI perah dengan $p$ value 0,420 .

\section{PEMBAHASAN}

ASI memiliki peran penting dalam tumbuh kembang bayi. Faktor psikologis menduduki peran penting dalam keberhasilan pemberian ASI secara eksklusif. Persepsi ibu merupakan bagian dari kondisi psikologis. Perceptions of Insufficient Milk Supply in Breastfeeding (PIM) adalah pendapat dimana ibu meyakini bahwa dia memiliki supplai ASI yang kurang/tidak cukup untuk memenuhi kebutuhan bayinya. PIM juga dikaitkan dengan rendahnya usaha ibu untuk menyusui bayinya akibat dari kurang percaya diri terhadap kemampuannya untuk memproduksi ASI yang cukup.

Hasil analisis data pada penelitian ini didapatkan kesimpulan bahwa ada hubungan yang bermakna antara PIM dengan volume ASI perah ibu bekerja di lingkungan UNUSA dengan $p$ value 0,009 . Hal ini sejalan dengan penelitan yang dilakukan Septian, 2017 dengan hasil pemberian ASI eksklusif lebih banyak pada kelompok responden yang memiliki sikap positif (72. 1\%) dibandingkan yang memiliki sikap negatif (40. 7\%). Hasil uji statistik diperoleh nilai $\mathrm{p}$ value $=0.001$, sehingga dapat disimpulkan bahwa ada hubungan yang signifikan antara sikap dengan pemberian ASI eksklusif.

Jika seorang ibu mempunyai pengalaman memompa ASI pada anak sebelumnya tentu akan mempengaruhi keyakinan ibu dalam memberikan ASI sehingga paritas juga akan mempengaruhi volume ASIP. Paritas adalah jumlah anak yang dilahirkan baik hidup maupun mati. Prevalensi menyusui eksklusif meningkat dengan bertambahnya jumlah anak, dimana prevalensi anak ketiga atau lebih akan lebih banyak disusui secara eksklusif dibandingkan anak kedua dan pertama. Pernyataan ini sejalan dengan penelitian yang dilakukan oleh Mursyida (2013) bahwa terdapat hubungan yang signifikan antara 
paritas dengan ASI eksklusif dengan $p$ value 0,004 . Hasil analisis pada penelitian ini memiliki hasil yang hampir sama dengan penelitian di atas yaitu terdapat hubungan yang bermakna antara volume ASI perah dengan paritas dengan $p$ value 0,012 .

Volume ASI perah tentu akan dipengaruhi oleh berapa kali ibu memerah ASI saat bekerja. Frekuensi memerah adalah berapa kali ibu memompa ASI selama bekerja, mulai jam 07.00 sampai jam 16.00 sesuai dengan jam kerja UNUSA. Pada penelitian ini 50\% ibu memompa sebanyak 2 kali selama bekerja. Hasil analisis data menunjukkan bahwa terdapat hubungan yang positif dan signifikan antara frekuensi memompa dengan volume ASI Perah. Hal tersebut sejalan dengan penelitian Rahmawati (2017) dengan hasil ada hubungan yang signifikan dan kuat antara frekuensi pemerahan dengan produksi ASI. Hubungan tersebut searah yang artinya semakin banyak frekuensi pemerahan, jumlah produksi ASI semakin meningkat.

Faktor lain yang berdasarkan teori mempengaruhi volume ASI Perah adalah IMT ibu, Usia ibu, alat yang digunakan untuk memompa, tempat memompa, dan alat kontrasepsi. Faktor tesebut di dalam penelitian ini ternyata tidak memiliki hubungan yang signifikan dengan volume ASI Perah ibu menyusui yang bekerja di lingkungan UNUSA. Hal ini dapat terjadi karena bnyaknya faktor perancu yang tidak bisa dihilangkan secara keseluruhan seperti kondisi psikologis ibu, kesehatan ibu, dan mood ibu padaa saat memompa.

\section{SIMPULAN}

Berdasarkan penelitian ini ada faktor yang mempengaruhi volume ASI Perah yaitu paritas, persepsi ibu tetang kecukupan ASI nya, dan frekuensi memerah. Untuk Indeks Massa Tubuh ibu, Usia ibu, alat yang digunakan untuk memompa, tempat memompa dan alat kontrasepsi tidak memiliki hubungan yang signifikan dengan volume ASI Perah ibu menyusui yang bekerja di Lingkungan UNUSA baik di Kampus A maupun di Kampus B.

\section{REKOMENDASI}

Untuk penelitian selanjutnya diharapkan dapat meneliti factor lain yang dapat mempengaruhi volume ASI seperti dukungan suami dan tempat bekerja. Penelitian lain juga memungkinkan untuk melihat perbedaan kualitas ASIP pada ibu bekerja dengan ibu yang tidak bekerja.

\section{REFERENSI}

Septian, Hanulan. 2017. Faktor-Faktor yang Berhubungan dengan Pemberian ASI Eksklusif Oleh Ibu Menyusui yang Bekerja Sebagai Tenaga Kesehatan. 
Aisyah: Jurnal Ilmu Kesehatan 2 2017, $159-174$

Mursyida, wadud. 2013. Hubungan Umur Ibu dan Paritas Ibu dengan Pemberian ASI Eksklusif pada Bayi berusia 0-6 Bulan di Puskesmas Pembina Palembang tahun 2013.

Perinasia. (2004). Manajemen Laktasi Rahmawati, Anita. 2017. Analisis Faktor Yang Mempengaruhi Produksi Air Susu Ibu (Asi) Pada Ibu Menyusui Yang Bekerja. Jurnal Ners dan Kebidanan: Volume 4, Nomor 2, Agustus 2017, hlm. 134-140

Roesli U., 2010. Inisiasi menyusu dini plus ASI eksklusif. Jakarta: Pustaka Bunda Survey Demografi Kesehatan Indonesia (SDKI). (2007)

World Health Organization (WHO). (2016). Global Strategy for Infant and young Child Feeding: The Optimal Duration of Exlusive Breastfeeding, 54 ${ }^{\text {th }}$ 